\title{
Bazı İki Sıralı Arpa (Hordeum vulgare conv. distichon) Çeşitlerinin Verim ve Verim Unsurları ile Bazı Kalite Özellikleri Üzerine Bir Araştırma
}

\author{
${ }^{*}$ Abdulveli SIRAT ${ }^{1}$ \\ İsmail SEZER ${ }^{2}$ \\ ${ }^{1}$ Gümüşhane Üniversitesi, Şiran Mustafa Beyaz MYO, Gümüşhane \\ ${ }^{2}$ Ondokuz Mayıs Üniversitesi, Ziraat Fakültesi Tarla Bitkileri Bölümü, Samsun \\ *Sorumlu yazar e-posta (Corresponding author; e-mail): awsirat@gumushane.edu.tr
}

\section{Öz}

Bu araştırma, 2008-2009 yetiştirme döneminde 12 adet iki sıralı arpa çeşidi (Fahrettinbey, Cumhuriyet50, Özdemir-05, Kalaycı-97, Çıldır-02, İnce-04, Efes-98, Erciyes, Çumra-2001, Sladoran, Tarm-92 ve Tokak157/35) ile Gökhöyük, Suluova ve Tokat lokasyonlarında Tesadüf Blokları Deneme Deseninde 4 tekrarlamalı olarak yürütülmüştür. Değişen çeşit ve çevre tane verimi ve diğer incelenen tüm özelliklerin istatistiki olarak $(P<0.01)$ önemli olduğu tespit edilmiştir. Çeşitlerin bitki boyu 92.26-119.29 cm, m²'deki başak sayısı $324.30-$ 430.96 adet, başak uzunluğu 6.58-9.11 cm, başaktaki tane sayısı 21.72-26.15 adet, tane verimi 280.55$426.71 \mathrm{~kg} / \mathrm{da}$, bin tane ağırlığı 32.14-41.54 g, hektolitre ağırığı 63.60-68.76 kg ve protein oranı ise \%12.38-14.00 arasında değişmiştir. En yüksek tane verimi ve en yüksek bin tane ağırığına Fahrettinbey ve Sladoran çeşitleri (sırasıyla $426.71 \mathrm{~kg} / \mathrm{da}$ ve $41.54 \mathrm{~g} ; 418.82 \mathrm{~kg} / \mathrm{da}$ ve $40.70 \mathrm{~g}$ ), en yüksek hektolitre ağırlığına Sladoran ve Fahrettinbey çeşitleri (sırasıyla 68.76 ve $67.63 \mathrm{~kg}$ ) ve en yüksek protein oranına ise Çıldır-02 çeşidi (\%14.00) sahip olmuştur.

Anahtar Kelimeler: Arpa, lokasyon, tane verimi ve verim unsurları, kalite özellikleri

\section{A Research on Yield and Yield Components with Some Quality Traits of Some Two-Rowed Barley (Hordeum vulgare conv. distichon) Cultivars}

\begin{abstract}
This research was carried out on 12 two-rowed barley varieties (Fahrettinbey, Cumhuriyet-50, Özdemir05, Kalaycı-97, Çıldır-02, İnce-04, Efes-98, Erciyes, Çumra-2001, Sladoran, Tarm-92 and Tokak-157/35) in a Randomized Complete Block Design with four replications in 2008-2009 growing season in Gökhöyük, Suluova and Tokat locations. It was determined that the effects of genotype and environment were significant at $1 \%$ level of probability for grain yield and all investigated traits. Plant height, spike number per $\mathrm{m}^{2}$, spike length, kernel number per spike, grain yield, 1000-seed weight, hectoliter weight and protein content values were determined for investigated genotypes respectively as between 92.26 and $119.29 \mathrm{~cm}, 324.30$ and 430.96, 6.58 and $9.11 \mathrm{~cm}, 21.72$ and $26.15,280.55$ and $426.71 \mathrm{~kg} / \mathrm{da}, 32.14$ and $41.54 \mathrm{~g}, 63.60$ and 68.76 $\mathrm{kg}, 12.38$ and $14.00 \%$.The cultivars Fahrettinbey and Sladoran sowed the highest grain yield and 1000seed weight ( $426.71 \mathrm{~kg} / \mathrm{da}$ and $41.54 \mathrm{~g} ; 418.82 \mathrm{~kg} / \mathrm{da}$ and $40.70 \mathrm{~g}$, respectively). The cultivars Sladoran and Fahrettinbey sowed the highest hectoliter weight (68.76 and $67.63 \mathrm{~kg}$ ), whereas the cultivars Çıldır-02 showed the highest protein content $(14.00 \%)$.
\end{abstract}

Keywords: Barley, location, grain yield and yield components, quality traits.

\section{Giriş}

T ürkiye'de en fazla üretilen serin iklim tahılları, buğday, arpa, yulaf ve çavdardır. Arpa, buğdaydan sonra en çok üretilen tahıl ürünüdür. Ülkemizde 1930'lu yıllarda 1.3 milyon ha alanda $89 \mathrm{~kg} / \mathrm{da}$ verimle üretimi yapılan arpanın, son yıllarda 2.7 milyon ha ekim alanı ve $290.4 \mathrm{~kg} / \mathrm{da}$ verimle 7.9 milyon ton yıllık üretim yapılmaktadır (Anonim 2014). Gelinen bu noktada tarım alanlarındaki genişlemenin yanında makineleşmenin, yetiştirme tekniği etkilerinin, kışa dayanıklı ve hastalıklara toleranslı çeşit ıslah edilmesinin katkıları da vardır. Dünya'da 49.781.046 hektar ekim alanı, 144.755.038 ton üretim ve verim 290.8 kg/da'dır (Anonim 2014). Üretilen arpanın \%85'i başta hayvan yemi olmak üzere değişik alanlarda değerlendirilirken, \%13- 
$15 ’ \mathrm{i}$ malt endüstrisinde hammadde olarak değerlendirilmektedir (Townsend 2008). Ülkemizde ise çoğunlukla hayvan yemi olarak değerlendirilen arpanın yaklaşık \%2.5'ini teşkil eden 200.000 tonluk kısmı malt sanayisinde kullanımaktadır. Ülkemiz malt sanayisinin işleme kapasitesinin 150.000 ton olduğu göz önüne alınırsa, maltıı arpa için miktar sorunu olmadığı söylenebilir. Ancak malt endüstrisinin intiyacı olan kaliteli maltlık arpa üretiminde yaşanan sorunlar dolayısıyla, zaman zaman ithalat yapılmaktadır (Başgül ve ark. 1999).

Bu çalışma ile Orta Karadeniz koşullarına uygun arpa genotiplerinin tane verimi ve bazı kalite özelliklerinin belirlenmesi, verim ve kalite özellikleri yönüyle üstün performans gösteren çeşitleri tespit ederek yaygınlaştırılması, ülke ekonomisine önemli katkıda bulunulması hedeflenmektedir.

\section{Materyal ve Yöntem}

Araştırma, 2008-2009 yetiştirme döneminde Gökhöyük Tarım İşletme Çiftliği, Suluova (İlçe Tarım Müdürlüğü Arazisi) ve Tokat (Artova Toprak ve Su Kaynakları Araştırma Enstitüsü Arazisi) lokasyonlarında yürütülmüştür. Çalışmada, iki sıralı arpa çeşitleri (Fahrettinbey, Cumhuriyet-50, Özdemir-05, Kalaycı-97, Çıldır02, İnce-04, Efes-98, Erciyes, Çumra-2001, Sladoran, Tarm-92 ve Tokak-157/35) kullanılmıştır. Deneme yerlerinde 0-40 cm derinliğinden ekim öncesi alınan toprak örneklerinin analiz sonuçlarına göre; Suluova lokasyonda tınlı; Gökhöyük ve Tokat lokasyonlarında ise killi-tınlı bir bünyeye sahiptir. Tuzluluk açısından, Suluova ve Tokat lokasyonlarının topraklarında hafif seviyede tuzluluk görülürken Gökhöyük çevresi ise topraklarının tuzsuz olduğu görülmektedir. Toprakların pH içerikleri 7.48-7.84 arasında değişmekte olup, Gökhöyük lokasyonu toprağı nötr, diğer çevreler ise hafif alkali olduğu belirlenmiştir. Deneme yerleri topraklarının tümünün orta seviyede kireçli olduğu tespit edilmiştir. Fosfor içeriği Gökhöyük, Suluova ve Tokat lokasyonlarında orta seviyede, potasyumun ise bütün çevrelerde yeterli olduğu belirlenmiştir. Organik madde ise Gökhöyük ve Tokat lokasyonundaki deneme topraklarında iyi, Suluova lokasyonun topraklarında ise orta seviyede olduğu tespit edilmiştir. Denemenin yürütüldüğü yerlere ait iklim verileri Çizelge 1'de verilmiştir. Araştırma, tesadüf blokları deneme desenine göre altı sıra olarak $6 \mathrm{~m}$ uzunluğunda ve $1.2 \mathrm{~m}$ genişliğindeki parsellere metrekarede 500 canlı tohum olacak şekilde, 4 tekrarlamalı olarak kurulmuştur. Hasatlar kenar tesir atıldıktan sonra kalan $4 \mathrm{~m}^{2}$ 'lik alan üzerinden yapılmıştır.

Denemelerde her parsele dekara $12 \mathrm{~kg} \mathrm{~N}$ ve $6 \mathrm{~kg} \mathrm{P}_{2} \mathrm{O}_{5}$ hesabıyla gübre verilmiştir. Verilen azotlu gübrenin yarısı ekimle birlikte DAP (Diamonyumfosfat), geri kalan yarısı ise sapa kalkma dönemi öncesinde CAN (Kalsiyum Amonyum Nitrat \%26 N) olarak uygulanmıştır (Köycü ve ark. 1988). Çalışmada elde edilen verilerin varyans analizleri çevreler üzerinden birleştirilerek MSTAT-C paket programı yardımıyla yapılmıştır (Düzgüneş ve ark. 1987).

Çizelge 1. Denemenin yürütüldüğü yerlerin bazı meteorolojik verileri*

Table 1. Some meteorological data from experiment locations

\begin{tabular}{|c|c|c|c|c|c|c|c|c|c|c|c|c|}
\hline \multirow[b]{2}{*}{ Yerler } & \multirow{2}{*}{$\begin{array}{c}\text { Meteorolojik } \\
\text { Veriler } \\
\text { (Aylık) }\end{array}$} & \multirow[b]{2}{*}{ Yillar } & \multicolumn{9}{|c|}{ AYLAR } & \multirow{2}{*}{$\begin{array}{l}\text { Vej. } \\
\text { Ort. } \\
\text { Top. }\end{array}$} \\
\hline & & & Ekim & Kasım & Aralık & Ocak & Şubat & Mart & Nisan & Mayıs & Haziran & \\
\hline \multirow{6}{*}{ Gökhöyük } & Ortalama & 2008-09 & 14.8 & 9.2 & 1.5 & 2.7 & 5.4 & 7.0 & 10.9 & 15.8 & 20.7 & 9.8 \\
\hline & Sicak. $\left(C^{\circ}\right)$ & Uzun Y. & 15.2 & 7.6 & 3.2 & 3.8 & 5.2 & 10.8 & 12.4 & 14.9 & 20.0 & 10.3 \\
\hline & Toplam & 2008-09 & 25.0 & 54.0 & 64.0 & 61.0 & 53.0 & 48.0 & 46.0 & 32.0 & 58.0 & 441.0 \\
\hline & Yağış (mm) & Uzun Y. & 25.4 & 53.8 & 44.7 & 34.8 & 35.0 & 41.3 & 43.1 & 33.3 & 30.3 & 341.7 \\
\hline & Ortalama & 2008-09 & 78.3 & 81.8 & 92.3 & 84.5 & 75.0 & 74.0 & 66.1 & 67.9 & 56.8 & 75.2 \\
\hline & N.Nem (\%) & Uzun Y. & 74.7 & 80.2 & 88.4 & 85.2 & 77.6 & 72.4 & 68.8 & 65.7 & 54.2 & 74.1 \\
\hline \multirow{6}{*}{ Suluova } & Ortalama & 2008-09 & 15.0 & 9.4 & 2.4 & 3.8 & 7.0 & 8.2 & 12.0 & 17.0 & 22.9 & 10.9 \\
\hline & Sicak. $\left(C^{\circ}\right)$ & Uzun Y. & 14.5 & 8.2 & 4.3 & 2.7 & 4.2 & 8.1 & 13.4 & 17.7 & 21.5 & 10.5 \\
\hline & Toplam & 2008-09 & 44.2 & 71.3 & 85.9 & 91.8 & 105.1 & 82.2 & 56.8 & 55.1 & 30.0 & 622.4 \\
\hline & Yağış (mm) & Uzun Y. & 38.4 & 49.5 & 47.4 & 47.9 & 35.8 & 44.2 & 59.8 & 51.6 & 36.4 & 411.0 \\
\hline & Ortalama & 2008-09 & 61.1 & 64.1 & 69.4 & 64.9 & 60.6 & 54.0 & 50.4 & 53.0 & 45.6 & 58.1 \\
\hline & N.Nem (\%) & Uzun Y. & 59.0 & 68.0 & 69.0 & 67.0 & 60.0 & 52.0 & 52.0 & 53.0 & 50.0 & 58.9 \\
\hline \multirow{6}{*}{ Tokat } & Ortalama & 2008-09 & 14.1 & 8.9 & 0.6 & 3.0 & 6.6 & 7.0 & 11.2 & 15.6 & 21.4 & 9.8 \\
\hline & Sicak. $\left(C^{\circ}\right)$ & Uzun Y. & 13.5 & 7.5 & 3.4 & 1.8 & 3.0 & 7.3 & 12.5 & 16.3 & 19.7 & 9.4 \\
\hline & Toplam & 2008-09 & 40.8 & 45.5 & 60.7 & 68.3 & 83.2 & 82.4 & 45.5 & 60.1 & 20.0 & 506.5 \\
\hline & Yağış (mm) & Uzun Y. & 45.3 & 48.6 & 42.1 & 40.8 & 33.3 & 39.0 & 60.0 & 62.1 & 36.9 & 408.1 \\
\hline & Ortalama & 2008-09 & 67.8 & 72.8 & 79.7 & 69.8 & 64.5 & 65.2 & 60.1 & 62.3 & 52.2 & 66.0 \\
\hline & N.Nem (\%) & Uzun Y. & 65.3 & 69.1 & 70.2 & 67.8 & 63.6 & 59.1 & 58.9 & 60.2 & 58.5 & 63.6 \\
\hline
\end{tabular}

*Gökhöyük Tarım İşletme Müdürlüğü, Amasya Meteoroloji İstasyon Müdürlüğü ve Tokat Meteoroloji Bölge Müdürlüğü

*Directionates of Gökhöyük Agricultural Facility, Amasya Meteorological Station and Tokat Meteorological Station 


\section{Bulgular ve Tartışma}

\section{Bitki Boyu}

Birleştirilmiş varyans analizi sonuçlarına göre denemede bitki boyu yönünden, yerler ve çeşitler arasında \%1 seviyesinde istatistiki olarak önemli bir farklılığın bulunduğu görülmüştür. Bitki boyu değerlerinin Tokat lokasyonu $(105.96 \mathrm{~cm})$, Gökhöyük $(102.30 \mathrm{~cm})$ ve Suluova $(100.81 \mathrm{~cm})$ lokasyonlarına göre daha yüksek olmuştur. Çeşitler arasında bitki boyunun $92.26 \mathrm{~cm}$ ile $119.29 \mathrm{~cm}$ arasında değiştiği görülmektedir. Bitki boyu olarak en düşük değerin Sladoran çeşidinde $(92.26 \mathrm{~cm})$, en yüksek bitki boyu değeri ise $119.29 \mathrm{~cm}$ ile Çumra-2001 çeşidinden elde edilmiştir (Çizelge 2). Lokasyon $x$ çeşit interaksiyonu incelendiğinde Suluova ve Tokat lokasyonlarında Çumra-2001 çeşidi sırasıyla 122.73 ve $121.83 \mathrm{~cm}$ ile en yüksek değere sahip olurken, aynı çeşidin Gökhöyük lokasyonunda $113.30 \mathrm{~cm}$ ile orta değere sahip olması, bu özelliğin çevre şartlarından etkilenebileceğinin bir göstergesidir. Bu araştırmada elde edilen değerlerin, Kendal ve ark. (2013)'nın bulgularıyla benzerlik, Akıncı ve Yıldırım (2013)'ın bulgularından düşük olduğu görülmektedir.

\section{Metrekaredeki Başak Sayısı}

Birleştirilmiş varyans analizi sonuçlarına göre, denemede lokasyon ortalamaları incelendiğinde, $\mathrm{m}^{2}$ 'de başak sayısının, Gökhöyük (401.82 adet) ve Tokat (391.26 adet) lokasyonları istatistiksel olarak aynı gurupta yer alırken, Suluova lokasyonunda $\mathrm{m}^{2}$ 'de başak sayısı ise 357.26 adet olduğu görülmüştür. Çeşitlerin $\mathrm{m}^{2}$ 'deki başak sayılarının 324.30 430.96 adet arasında değiştiği görülmektedir. Metrekarede başak sayısı olarak en düşük değer Çıldır-02 ve Efes-98 (324.30 ve 332.55 adet) çeşitlerinde, en yüksek değeri ise istatistiksel olarak aynı grupta yer alan Fahrettinbey ve Sladoran çeşitlerinden (sırasıyla 430.96, 430.71 adet) elde edilmiştir (Çizelge 2).

Çeşitler arasında metrekarede başak sayısı bakımından görülen bu farklıık, çeşitlerin genetik yapılarından ve çevrelerin farklı olmasından kaynaklanmış olabilir. Bu değerler, Kaydan ve Yağmur (2007)'un sonuçlarıyla benzerlik göstermektedir. Lokasyon $\mathrm{x}$ çeşit interaksiyonu açısından incelendiğinde, Fahrettinbey ve Sladoran çeşitlerinin $\mathrm{m}^{2} \mathrm{de}$ 454.88 ve 451.38 adet başak ile Tokat lokasyonunda en yüksek değerlere sahip olduğu, Gökhöyük (428.13 ve 442.13 adet) ve Suluova'da (409.88 ve 398.63 adet) ise alt sıralarda yer aldığı görülmektedir (Çizelge 2). Bu durum genotiplerin kardeşlenmesi ve başak sayısının lokasyonlara göre önemli ölçüde değişebileceğini göstermektedir.

\section{Başak Uzunluğu}

Birleştirilmiş varyans analizi sonuçlarına göre, başak uzunluğu değerlerinin Gökhöyük lokasyonunda $7.16 \mathrm{~cm}$, Suluova lokasyonunda $7.28 \mathrm{~cm}$ ve Tokat lokasyonunda ise $7.69 \mathrm{~cm}$ saptanmıştır. Lokasyon $\mathrm{x}$ çeşit interaksiyonu incelendiğinde Tokat ve Suluova lokasyonlarında Fahrettinbey çeşidi (sırasıyla $9.65,9.28 \mathrm{~cm}$ ) en yüksek değere sahip olurken,

Çizelge 2. Denemede kullanılan arpa çeşitlerine ait bitki boyu ve metrekare'deki başak sayısına ilişkin ortalama değerler ve ortalamaların farklılık gruplandırmaları

Table 2. Plant height and spike number per squaremeter averages of barley varieties and LSD groups

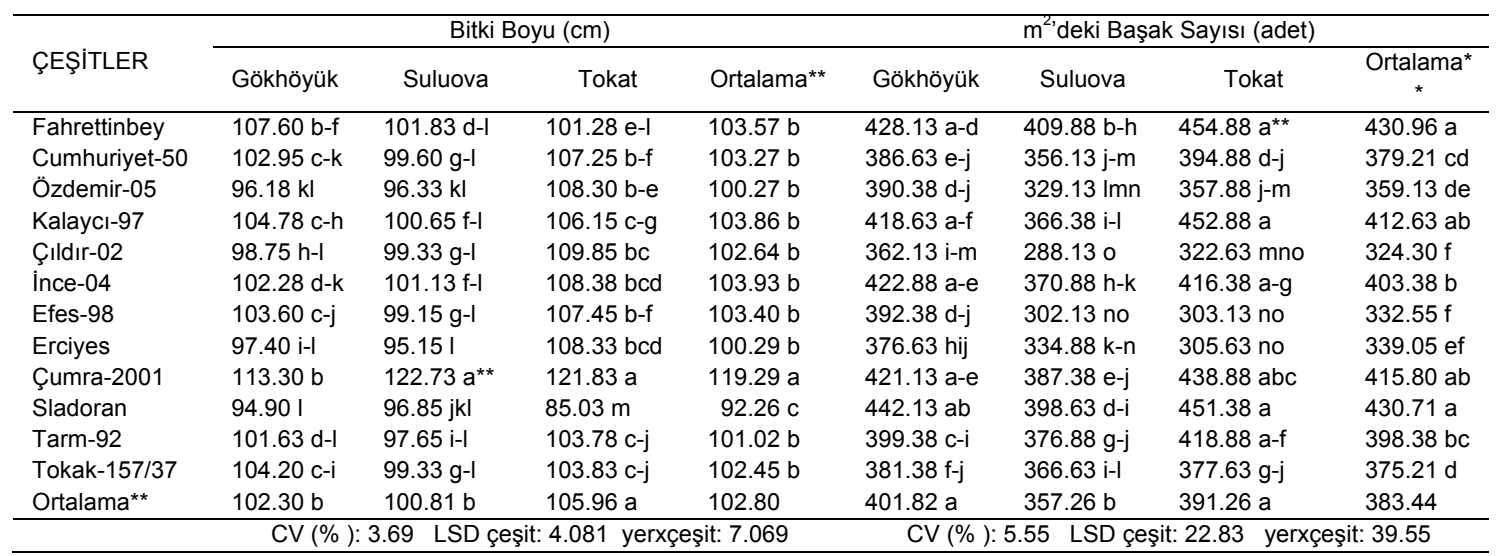

Aynı harf ile gösterilen ortalamalar arasındaki ${ }^{*} \mathrm{P}<0.05$, ${ }^{*} \mathrm{P}<0.01$ olasılıkla fark yoktur.

Averages followed by same letter are not statistically different at ${ }^{*} P<0.05$ and ${ }^{* *} P<0.01$ levels. 
aynı çeşidin Gökhöyük lokasyonunda $8.40 \mathrm{~cm}$ ile orta değere sahip olması, bu özelliğin çevre şartlarından etkilenebileceğinin bir göstergesidir. Çeşitler arasında başak uzunluğunun $6.58 \mathrm{~cm}$ ile $9.11 \mathrm{~cm}$ arasında değiştiği görülmektedir. En yüksek başak boyu değeri ise $9.11 \mathrm{~cm}$ ile Fahrettinbey çeşidinden elde edilmiştir (Çizelge 3). Genotipler arasında başak uzunluğu bakımından görülen farklılıklar genetik yapılarından kaynaklandığı düşünülmektedir.

\section{Başakta Tane Sayısı}

Başakta tane sayısı bakımından çeşitler istatistikî olarak çok önemli çıkmıştır. Başakta tane sayısı, yerler ve çeşitler ortalaması olarak en fazla Fahrettinbey (26.15 adet), Çumra-2001 (25.93 adet) ve Sladoran (25.31 adet) çeşitlerinde görülürken, en az başakta tane sayısı ise Efes-98 (21.72 adet) çeşidinde tespit edilmiştir. Ayrıca Tokat lokasyonunda çeşitler ortalaması olarak başakta tane sayısı, 24.10 adet, Suluova lokasyonunda 23.44 adet ve Gökhöyük lokasyonunda ise 22.77 adet olarak belirlenmiştir (Çizelge 3). Başakta tane sayısı tahıllarda doğrudan verimi etkileyen bir bitkisel özelliktir (Şehirali ve ark. 2001). Başakta tane sayısının çeşitlere göre önemli farklılık gösterdiği birçok araştıııcı tarafından belirtilmiştir (Mut ve ark. 2010; Akıncı ve Yıldııım 2013).

\section{Tane Verimi}

Çalışmada lokasyonlar ve çeşitler arası farklılıklar ile çeşit $x$ lokasyon interaksiyonu istatistiksel olarak \%1 düzeyinde önemli olmuştur. Çizelge 4'te görüldüğü gibi Tokat lokasyonundan $424.67 \mathrm{~kg} / \mathrm{da}$ en yüksek tane verimi elde edilirken, Gökhöyük ve Suluova lokasyonlarından ortalama tane verimi sırasıyla 352.83 ve $286.80 \mathrm{~kg} / \mathrm{da}$ elde edilmiştir. Çeşitlerin tane veriminin $280.55-426.71 \mathrm{~kg} / \mathrm{da}$ arasında değiştiği görülmektedir. En yüksek birim alan tane verimi ortalama $426.71 \mathrm{~kg} / \mathrm{da}$ ile Fahrettinbey çeşidinden elde edilirken en düşük birim alan tane verimi ise $280.55 \mathrm{~kg} / \mathrm{da}$ ile Çıldır02 çeşidinden elde edilmiştir (Çizelge 4).

Farklı çeşitlerin farklı bölgelerde farklı performans göstermesi beklenen bir sonuçtur. Daha önce yapılan çalışmalarda bu çalışmanın yürütüldüğü bölge ekolojisine benzer yerlerde benzer sonuçlar elde edilirken (Mut ve ark. 2010; Sirat ve ark. 2012), yapılan bu çalışmalardan elde edilen sonuçlara bakıldığında, ekoloji değiştikçe verimde de olumlu veya olumsuz yönde önemli değişiklilikler olduğu görülmüştür. Sirat ve Sezer (2013) Samsun koşullarında yürüttükleri çalışmada arpa çeşitlerinden ortalama 188.84$620.28 \mathrm{~kg} / \mathrm{da}$ arasında tane verimi, Mut ve ark. (2014) Samsun koşullarında yürüttükleri çalışmada arpa çeşitlerinden ortalama 314.9$474.7 \mathrm{~kg} / \mathrm{da}$ tane verimi alırken, Çölkesen ve ark. (1999)'nin Kahramanmaraş koşullarında çeşit verim denemesinde arpa çeşitlerinden ortalama $672-780 \mathrm{~kg} / \mathrm{da}$ tane verimi almışlardır. Bu sonuçlar, çeşitlerin farklı ekolojilere farkı tepki gösterdiklerini açıkça ortaya koymaktadır. Lokasyon $\mathrm{x}$ çeşit interaksiyonu incelendiğinde birbirine yakın bölgelerde bile çeşitlerin ekolojiye farklı tepki verdikleri görülmektedir. Tokat lokasyonunda Fahrettinbey çeşidi 519.63 $\mathrm{kg} / \mathrm{da}$ ile en yüksek tane verimi verirken, Gökhöyük ve Suluova lokasyonlarından en yüksek tane verimi sırasıyla Sladoran (400.88 $\mathrm{kg} / \mathrm{da}$ ) ve Fahrettinbey $377.63 \mathrm{~kg} / \mathrm{da}$ alınmıştır (Çizelge 4).

Çizelge 3. Denemede kullanılan arpa çeşitlerine ait başak uzunluğu ve başakta tane sayısına ilişkin ortalama değerler ve ortalamaların farklılık gruplandırmaları

Table 3. Spike length and kernel number per spike averages of barley varieties and LSD groups

\begin{tabular}{|c|c|c|c|c|c|c|c|c|}
\hline \multirow{2}{*}{ ÇEŞITLER } & \multicolumn{4}{|c|}{ Başak Uzunluğu (cm) } & \multicolumn{4}{|c|}{ Başakta Tane Sayısı (adet) } \\
\hline & Gökhöyük & Suluova & Tokat & Ortalama $^{\star \star}$ & Gökhöyük & Suluova & Tokat & Ortalama** \\
\hline Fahrettinbey & $8.40 \mathrm{~b}$ & $9.28 \mathrm{a}$ & $9.65 \mathrm{a}^{\star \star}$ & $9.11 \mathrm{a}$ & 25.35 a-d & $26.55 a b$ & $26.55 a b$ & $26.15 a$ \\
\hline Cumhuriyet-50 & $7.48 \mathrm{~d}-\mathrm{h}$ & $7.18 \mathrm{e}-\mathrm{i}$ & $7.65 \mathrm{c}-\mathrm{g}$ & $7.44 \mathrm{~cd}$ & $23.00 \mathrm{f}-\mathrm{I}$ & $23.03 f-I$ & $23.28 \mathrm{e}-1$ & $23.10 \mathrm{~b}$ \\
\hline Özdemir-05 & 6.131 & $6.68 \mathrm{i}-\mathrm{I}$ & $7.48 \mathrm{~d}-\mathrm{h}$ & $6.76 \mathrm{f}$ & $20.10 \mathrm{~m}$ & $22.55 \mathrm{~g}-\mathrm{I}$ & 23.33 e-k & $21.99 \mathrm{~cd}$ \\
\hline Kalaycı-97 & $7.15 \mathrm{f}-\mathrm{j}$ & $7.25 \mathrm{~d}-\mathrm{i}$ & $7.85 b-f$ & $7.42 \mathrm{~cd}$ & $22.48 \mathrm{~h}-\mathrm{I}$ & $23.95 c-i$ & $23.78 \mathrm{c}-\mathrm{j}$ & $23.40 \mathrm{~b}$ \\
\hline Çıldır-02 & 6.181 & 6.281 & $7.40 \mathrm{~d}-\mathrm{h}$ & $6.62 \mathrm{f}$ & $20.20 \mathrm{~m}$ & $21.83 \mathrm{klm}$ & $23.45 \mathrm{e}-\mathrm{k}$ & $21.83 \mathrm{~cd}$ \\
\hline İnce-04 & $6.40 \mathrm{kl}$ & $7.88 \mathrm{~b}-\mathrm{e}$ & $7.38 \mathrm{~d}-\mathrm{i}$ & $7.22 \mathrm{de}$ & $21.83 \mathrm{klm}$ & $24.70 b-f$ & $24.25 \mathrm{c}-\mathrm{h}$ & $23.59 \mathrm{~b}$ \\
\hline Efes-98 & 6.181 & $6.45 \mathrm{jkl}$ & $7.10 \mathrm{~g}-\mathrm{k}$ & $6.58 \mathrm{f}$ & $20.18 \mathrm{~m}$ & $21.43 \mathrm{Im}$ & $23.55 \mathrm{~d}-\mathrm{k}$ & $21.72 d$ \\
\hline Erciyes & $7.70 \mathrm{~b}-\mathrm{g}$ & $6.78 \mathrm{~h}-\mathrm{I}$ & $7.90 \mathrm{bcd}$ & $7.46 \mathrm{~cd}$ & $22.45 \mathrm{~h}-\mathrm{I}$ & 22.40 h-I & $23.53 \mathrm{~d}-\mathrm{k}$ & $22.79 \mathrm{bcd}$ \\
\hline Çumra-2001 & $7.83 \mathrm{~b}-\mathrm{f}$ & $8.33 b c$ & $8.33 b c$ & $8.16 \mathrm{~b}$ & 25.05 b-e & $25.60 \mathrm{abc}$ & $27.13 a^{* \star}$ & $25.93 \mathrm{a}$ \\
\hline Sladoran & $7.75 \mathrm{~b}-\mathrm{g}$ & $7.95 \mathrm{bcd}$ & $7.35 \mathrm{~d}-\mathrm{i}$ & $7.68 \mathrm{c}$ & $26.45 a b$ & 25.05 b-e & $24.43 \mathrm{c}-\mathrm{g}$ & $25.31 \mathrm{a}$ \\
\hline Tarm-92 & $7.45 \mathrm{~d}-\mathrm{h}$ & $7.05 \mathrm{~g}-\mathrm{k}$ & $7.08 \mathrm{~g}-\mathrm{k}$ & $7.19 \mathrm{de}$ & $23.18 \mathrm{e}-\mathrm{I}$ & $22.20 \mathrm{i}-\mathrm{I}$ & $23.23 \mathrm{e}-\mathrm{I}$ & $22.87 \mathrm{bc}$ \\
\hline Tokak-157/37 & $7.30 \mathrm{~d}-\mathrm{i}$ & 6.301 & $7.08 \mathrm{~g}-\mathrm{k}$ & 6.89 ef & $22.98 \mathrm{f}-\mathrm{I}$ & $21.98 \mathrm{j}-\mathrm{m}$ & $22.70 \mathrm{~g}-1$ & $22.55 \mathrm{bcd}$ \\
\hline Ortalama** & $7.16 \mathrm{c}$ & $7.28 \mathrm{~b}$ & $7.69 \mathrm{a}$ & 7.38 & $22.77 \mathrm{c}$ & $23.44 b$ & $24.10 \mathrm{a}$ & 23.44 \\
\hline
\end{tabular}

Aynı harf ile gösterilen ortalamalar arasındaki ${ }^{*} \mathrm{P}<0.05$, ${ }^{*} \mathrm{P}<0.01$ olasılıkla fark yoktur.

Averages followed by same letter are not statistically different at ${ }^{*} P<0.05$ and ${ }^{* *} P<0.01$ levels. 
Çizelge 4. Denemede kullanılan arpa çeşitlerine ait tane verimi ve bin tane ağırlığına ilişkin ortalama değerler ve ortalamaların farklılık gruplandırmaları

Table 4. Grain yield and 1000-seed weight averages of barley varieties and LSD groups

\begin{tabular}{|c|c|c|c|c|c|c|c|c|}
\hline \multirow{2}{*}{ ÇEŞiTLER } & \multicolumn{4}{|c|}{ Tane Verimi $(\mathrm{kg} / \mathrm{da})$} & \multicolumn{4}{|c|}{ Bin Tane Ağırlığı (g) } \\
\hline & Gökhöyük & Suluova & Tokat & Ortalama** & Gökhöyük & Suluova & Tokat & Ortalama** \\
\hline Fahrettinbey & $382.9 \mathrm{~d}-\mathrm{g}$ & 377.6 d-h & $519.63 \mathrm{a}^{\star *}$ & $426.71 \mathrm{a}$ & $36.94 \mathrm{f}-\mathrm{j}$ & 38.46 efg & $49.23 \mathrm{a}^{* *}$ & $41.54 \mathrm{a}$ \\
\hline Cumhuriyet-50 & $343.9 \mathrm{~g}-\mathrm{I}$ & $285.9 \mathrm{~m}-\mathrm{p}$ & $419.88 \mathrm{~cd}$ & $349.88 \mathrm{e}$ & 33.36 I-p & $33.74 \mathrm{k}-\mathrm{o}$ & $40.15 \mathrm{de}$ & $35.75 \mathrm{~cd}$ \\
\hline Özdemir-05 & $331.0 \mathrm{i}-\mathrm{m}$ & 238.4 qrs & $383.38 \mathrm{~d}-\mathrm{g}$ & $317.59 \mathrm{fg}$ & $33.001-p$ & $31.68 \mathrm{~m}-\mathrm{p}$ & $38.44 \mathrm{efg}$ & $34.37 \mathrm{de}$ \\
\hline Kalaycı-97 & $366.4 \mathrm{e}-\mathrm{i}$ & 316.9 k-n & $498.13 \mathrm{ab}$ & $393.80 \mathrm{bc}$ & $34.66 \mathrm{i}-\mathrm{I}$ & $34.80 \mathrm{~h}-\mathrm{I}$ & $42.27 \mathrm{~cd}$ & $37.24 \mathrm{bc}$ \\
\hline Çıldır-02 & $307.6 \mathrm{I}-\mathrm{O}$ & $217.9 \mathrm{~s}$ & $316.13 \mathrm{k}-\mathrm{n}$ & $280.55 \mathrm{~h}$ & 31.16 nop & 30.91 op & $34.36 \mathrm{j}-\mathrm{m}$ & $32.14 \mathrm{f}$ \\
\hline İnce-04 & $363.6 \mathrm{e}-\mathrm{j}$ & $318.4 j-n$ & $463.63 \mathrm{bc}$ & $381.88 \mathrm{~cd}$ & $35.01 \mathrm{~h}-\mathrm{I}$ & $34.44 \mathrm{i}-\mathrm{m}$ & $43.11 \mathrm{c}$ & $37.52 \mathrm{~b}$ \\
\hline Efes-98 & 335.4 h-I & $227.9 \mathrm{rs}$ & $314.88 \mathrm{k}-\mathrm{o}$ & $292.71 \mathrm{gh}$ & $32.491-p$ & $30.59 p$ & $35.38 \mathrm{~h}-\mathrm{I}$ & 32.82 ef \\
\hline Erciyes & $332.1 \mathrm{~h}-\mathrm{I}$ & $240.9 p-s$ & $320.63 \mathrm{i}-\mathrm{n}$ & $297.88 \mathrm{gh}$ & $34.18 \mathrm{j}-\mathrm{m}$ & $33.60 \mathrm{l}-\mathrm{o}$ & 39.66 def & $35.81 \mathrm{~cd}$ \\
\hline Çumra-2001 & $377.9 \mathrm{~d}-\mathrm{h}$ & $325.6 \mathrm{i}-\mathrm{m}$ & $507.31 \mathrm{ab}$ & $403.61 \mathrm{abc}$ & $37.32 \mathrm{e}-\mathrm{i}$ & $34.95 \mathrm{~h}-\mathrm{I}$ & $44.36 \mathrm{bc}$ & $38.88 \mathrm{~b}$ \\
\hline Sladoran & $400.9 \mathrm{de}$ & $347.4 \mathrm{~g}-\mathrm{I}$ & $508.13 a b$ & $418.82 \mathrm{ab}$ & $39.04 \mathrm{efg}$ & $36.64 \mathrm{~g}-\mathrm{k}$ & $46.43 \mathrm{ab}$ & $40.70 \mathrm{a}$ \\
\hline Tarm-92 & $354.6 \mathrm{f}-\mathrm{k}$ & $274.8 n-q$ & $449.63 \mathrm{c}$ & $359.69 \mathrm{de}$ & 33.97 k-n & $32.721-p$ & $37.68 \mathrm{e}-\mathrm{h}$ & $34.79 \mathrm{~d}$ \\
\hline Tokak-157/37 & $337.6 \mathrm{~g}-\mathrm{I}$ & 269.9 o-r & 394.63 def & 334.05 ef & 32.96 I-p & $33.051-p$ & $36.60 \mathrm{~g}-\mathrm{k}$ & $34.20 \mathrm{de}$ \\
\hline \multirow[t]{2}{*}{ Ortalama** } & $352.8 b$ & $286.8 \mathrm{c}$ & $424.67 \mathrm{a}$ & 354.76 & $34.51 \mathrm{~b}$ & $33.80 \mathrm{~b}$ & $40.64 \mathrm{a}$ & 36.32 \\
\hline & CV (\%): 7.00 & LSD çeşit: & 64 yerxçeşi & 46.15 & CV $(\%): 4$. & LSD çeş & .698 ye & şit: 2.942 \\
\hline
\end{tabular}

Aynı harf ile gösterilen ortalamalar arasındaki ${ }^{*} P<0.05$, ${ }^{* *} P<0.01$ olasılıkla fark yoktur.

Averages followed by same letter are not statistically different at ${ }^{*} P<0.05$ and ${ }^{* *} P<0.01$ levels.

\section{Bin Tane Ağırı̆̆ı}

Birleştirilmiş varyans analizi sonuçlarına göre denemede bin tane ağırlığı yönünden, lokasyonlar ve çeşitler arasında \%1 seviyesinde önemli çıkmıştır (Çizelge 4). Lokasyon ortalamaları incelendiğinde, bin tane ağırlığı Tokat, Gökhöyük ve Suluova lokasyonlarında sırasıyla $40.64 \mathrm{~g}, \quad 34.51 \mathrm{~g}$ ve $33.80 \mathrm{~g}$ görülmektedir. Çeşitler arasında bin tane ağırlığı 32.14-41.54 g arasında değişmiştir. Bin tane ağırığı olarak en düşük değerin $32.14 \mathrm{~g}$ ile Çıldır-02 çeşidinden elde edildiği, en yüksek değerlerin ise istatistiki olarak ayn grupta yer alan Fahrettinbey ve Sladoran çeşitlerinden sırasıyla 41.54-40.70 g ile elde edildiği belirlenmiştir (Çizelge 4). Elde edilen bu değerlerin, Karahan ve Sabancı (2010), Mut ve ark. (2010) ve Sirat (2014)'ın değerlerine benzerlik olduğu, Mut ve ark. (2014)'nın değerlerinden daha düşük olduğu görülmektedir.

\section{Hektolitre Ağırlığı}

Birleştirilmiş varyans analizi sonuçlarına göre denemede hektolitre ağırığı bakımından lokasyonlar arasında ve çeşit ve çevreler arasında \%1 seviyesinde önemli farklılık tespit edilmiştir. Bu çalışmada lokasyon ortalama değerleri sırasıyla 65.66 kg (Göhöyük), $64.93 \mathrm{~kg}$ (Suluova) ve $66.77 \mathrm{~kg}$ (Tokat) olmuştur. Araştırmada çeşitlerin hektolitre ağırlıklarının 63.60-68.76 kg arasında değiştiği, çeşit düzeyinde hektolitre ağılıklarına bakıldığında, en yüksek değerin sırasıyla 68.76, 67.63 ve 67.60 kg ile Sladoran, Fahrettinbey ve Çumra-2001 çeşitlerinden en düşük değeri ise $63.60 \mathrm{~kg}$ ile Çıldır-02 çeşidinden elde edilmiştir (Çizelge 5).

Çizelge 5. Denemede kullanılan arpa çeşitlerine ait hektolitre ağırlığı ve protein oranına ilişkin ortalama değerler ve ortalamaların farklılık gruplandırmaları

Table 5. Hectoliter weight and protein averages of barley varieties and LSD groups

\begin{tabular}{|c|c|c|c|c|c|c|c|c|}
\hline \multirow{2}{*}{ ÇEŞITLER } & \multicolumn{4}{|c|}{ Hektolitre Ağırlığı (kg) } & \multicolumn{4}{|c|}{ Protein Oranı (\% ) } \\
\hline & Gökhöyük & Suluova & Tokat & Ortalama** & Gökhöyük & Suluova & Tokat & Ortalama** \\
\hline Fahrettinbey & 67.59 & 66.93 & 68.37 & $67.63 \mathrm{ab}$ & $12.98 \mathrm{jkl}$ & $12.83 \mathrm{Im}$ & $11.80 \mathrm{q}$ & $12.54 \mathrm{f}$ \\
\hline Cumhuriyet-50 & 64.80 & 63.61 & 66.77 & 65.06 cde & $13.76 \mathrm{c}$ & 13.42 ef & 12.30 no & $13.16 \mathrm{~d}$ \\
\hline Özdemir-05 & 63.81 & 63.11 & 65.82 & $64.25 \mathrm{de}$ & $14.12 a b$ & $13.52 \mathrm{def}$ & $13.67 \mathrm{~cd}$ & $13.77 b$ \\
\hline Kalaycı-97 & 65.87 & 64.89 & 67.64 & $66.13 \mathrm{bc}$ & $12.46 n$ & $11.97 p$ & $12.73 \mathrm{~m}$ & $12.39 \mathrm{~g}$ \\
\hline Çıldır-02 & 63.48 & 62.79 & 64.53 & $63.60 \mathrm{e}$ & $14.01 \mathrm{~b}$ & $13.75 \mathrm{c}$ & $14.24 \mathrm{a}^{* *}$ & $14.00 \mathrm{a}$ \\
\hline İnce-04 & 66.59 & 66.94 & 67.43 & $66.99 \mathrm{~b}$ & $13.68 \mathrm{~cd}$ & $13.36 \mathrm{fg}$ & $13.39 \mathrm{efg}$ & $13.48 \mathrm{c}$ \\
\hline Efes-98 & 64.70 & 62.50 & 64.73 & $63.98 \mathrm{de}$ & $14.23 \mathrm{a}$ & $13.55 \mathrm{de}$ & $13.77 \mathrm{c}$ & $13.85 b$ \\
\hline Erciyes & 64.80 & 64.31 & 66.20 & 65.10 cde & $13.77 \mathrm{c}$ & $13.56 \mathrm{de}$ & 12.25 o & $13.19 \mathrm{~d}$ \\
\hline Çumra-2001 & 67.03 & 67.57 & 68.21 & $67.60 \mathrm{ab}$ & $12.96 \mathrm{kl}$ & 12.250 & $12.01 p$ & $12.41 \mathrm{~g}$ \\
\hline Sladoran & 69.83 & 68.02 & 68.43 & $68.76 \mathrm{a}$ & $12.84 \mathrm{Im}$ & 12.33 no & $11.98 p$ & $12.38 \mathrm{~g}$ \\
\hline Tarm-92 & 64.84 & 63.72 & 66.45 & $65.00 \mathrm{cde}$ & $12.95 \mathrm{kl}$ & $13.25 \mathrm{gh}$ & 12.99 jkl & $13.06 \mathrm{e}$ \\
\hline Tokak-157/37 & 64.52 & 64.79 & 66.61 & $65.31 \mathrm{~cd}$ & $13.13 \mathrm{hij}$ & $13.18 \mathrm{hi}$ & 13.07 ijk & $13.13 \mathrm{de}$ \\
\hline \multirow[t]{2}{*}{ Ortalama** } & $65.66 \mathrm{~b}$ & $64.93 \mathrm{~b}$ & $66.77 \mathrm{a}$ & 65.78 & $13.41 \mathrm{a}$ & $13.08 \mathrm{~b}$ & $12.85 \mathrm{c}$ & 13.11 \\
\hline & & $(\%): 2.25$ & LSD çeş & 1.586 & CV $(\%$ & 67 LSD & it: 0.096 & xçeşit: 0.166 \\
\hline
\end{tabular}

Aynı harf ile gösterilen ortalamalar arasındaki ${ }^{*} \mathrm{P}<0.05,{ }^{*} \mathrm{P}<0.01$ olasılıkla fark yoktur.

Averages followed by same letter are not statistically different at ${ }^{*} P<0.05$ and ${ }^{* *} P<0.01$ levels. 
Araştırmadan elde edilen hektolitre ağırığı değerleri, Mut ve ark. (2010, 2014) ve Sirat (2014)'ın farklı ekolojik şartlarda elde edilen sonuçlarla benzerlik göstermektedir.

\section{Protein Oranı}

Lokasyon ortalamaları incelendiğinde, tanede protein oranı Gökhöyük lokasyonunda $\% 13.41$, Suluova ve Tokat lokasyonlarında ise sırasıyla \%13.08-12.85 tespit edilmiştir. Çeşitlerin protein oranının \%12.38-14.00 arasında değiştiği görülmekte, en düşük protein oranı değerin istatistiki olarak aynı grupta yer alan Sladoran, Kalaycı-97, Çumra-2001 ve Fahrettinbey çeşitlerinden sırasıyla \%12.38, $12.39,12.41$ ve 12.54 ile elde edildiği, en yüksek oranının ise Çıldır-02 çeşidinden $\% 14.00$ ile elde edildiği görülmektedir (Çizelge 5). Lokasyon x çeşit interaksiyon tablosu incelendiğinde en düşük tanede protein oranı Tokat lokasyonunda, Fahrettinbey çeşidinden (\%11.80) elde edilirken, en yüksek tanede protein oranı ise yine Tokat lokasyonunda Çıldır-02 çeşidinden \%14.24 olmuş, aynı çeşidin Gökhöyük ve Suluova lokasyonlarında \%14.01-13.75 ile orta derece değere sahip olması, bu özelliğin çevre şartlarından etkilenebileceğinin bir göstergesidir (Çizelge 5). Protein oranı bakımından genotipler arasında önemli farkların olduğu birçok araştırıcı tarafından bildirilmiştir (Karahan ve Sabancı 2010; Sirat 2014).

\section{Sonuç}

2008-2009 yetiştirme dönemlerinde Gökhöyük, Suluova ve Tokat ekolojik koşullarında denemeye alınan 12 adet iki sıralı arpa genotipi ile yürütülen bu çalışmada, en yüksek tane verimi Fahrettinbey $(426.71 \mathrm{~kg} / \mathrm{da})$ çeşidinden elde edilmiştir. Genel olarak başak uzunluğu, başakta tane sayısı ve metrekarede başak sayısı fazla olan çeşitlerin tane verimleri de yüksek olmuştur. Bin tane ağırlığı en yüksek Fahrettinbey ve Sladoran çeşitlerinden, hektolitre ağırlığı ise en yüksek Sladoran ve Fahrettinbey genotiplerden elde edilmiştir. En uzun bitki boyu Çumra-2001 çeşidi ve en kısa bitki boyu ise Sladoran çeşidinde görülmüştür. Yemlik ve maltıı sınıflandırmada kullanılan protein oranı bakımından en düşük değerler Sladoran, Kalaycı-97, Çumra-2001 ve Fahrettinbey çeşitlerinde, en yüksek oranı ise Çıldır-02 çeşidinde tespit edilmiştir. Yapılan bir yıllık çalışma sonucunda, verim ve kalite birlikte düşünüldüğünde Fahrettinbey, Sladoran ve Çumra-2001'in bölgede geniş alanlarda birkaç yıl daha ve farklı çevrelerde, özellikle çiftçi koşullarında test edilmesi, sulu ve kurak şartlarda denenmesi, daha güvenilir sonuçların elde edilmesinde ve daha sağlıklı karar verilmesinde büyük yarar sağlayacaktır.

\section{Kaynaklar}

Akıncı C. ve Yıldırım M., 2013. Bazı Arpa (Hordeum vulgare) Genotiplerinin Adana ve Diyarbakır Koşullarında Verim ve Verim Bileşenlerinin İncelenmesi. Türkiye 10. Tarla Bitkileri Kongresi, 10-13 Eylül, s. 393-397, Konya

Anonim, 2014. FAO production year book. food and agriculture organisation of united nations, Roma.Alıntı;http://faostat.fao.org/site/567/defa ult.aspx\#ancor (http:// www.fao.org/organic ag/) (Erişim tarihi: 12.12.2014)

Başgül A., Engin A., Özkara R. ve Yücalan T., 1999. Efes Pilsen Arpa Geliştirme Çalışmaları. Hububat Sempozyumu, s. 602-607, Konya

Çölkesen M., Cesurer L., Yürürdurmaz C., Demirbağ V., Çiçek A., Başgül A. ve Engin A., 1999. Kahramanmaraş Koşullarına Uygun Yüksek Verimli Arpa Çeşitlerinin Belirlenmesi. Türkiye III. Tarla Bitkileri Kongresi. s: 234-239, Adana

Düzgüneş O., Kesici T., Kavuncu O., Gürbüz F., 1987. Araştırma ve Deneme Metotları (İstatistik Metotları-II). Ankara Üniv. Zir. Fak. Yay. No: 1021, Ders Kitabı, No: 295, Ankara

Karahan T. ve Sabancı C.O., 2010. Güneydoğu anadolu ekolojik koşullarında bazı arpa (Hordeum vulgare L.) çeşitlerinin verim ve verim öğelerinin belirlenmesi. Batı Akdeniz Tarımsal Araştırma Enstitüsü Derim Dergisi, 27(1): 1-11

Kaydan D. ve Yağmur M., 2007. Van ekolojik koşularında bazı iki sıralı arpa çeşitlerinin (Hordeum vulgare L. conv. distichon) verim ve verim öğeleri üzerine bir araştırma. Ankara Üniv. Ziraat Fakültesi, Tarım Bilimleri Dergisi, 13(3): 269-278

Kendal E., Tekdal S., Aktaş H. ve Karaman M., 2013. Bazı Yazlık Arpa Genotiplerinin Çeşit Geliştirme Programı Kapsamında Değerlendirilmesi. Türkiye 10. Tarla Bitkileri Kongresi, 10-13 Eylül, s. 578-583, Konya

Köycü C., Sezer İ., Bulanık N. ve Kurt O., 1988. Samsun ekolojik şartlarında yetiştirilen arpanın tane verim ile bazı kalite karakterlerine n.p.k.'lı gübrelerin etkileri üzerinde bir araştırma. OMÜ Ziraat Fak. Dergisi, 3(2): 159-170

Mut Z., Gülümser A. and Sirat A., 2010. comparison of stability statistics for yield in barley (Hordeum vulgare L.). African Journal of Biotechnology, 9(11): 1610-1618 

Barley (Hordeum vulgare conv. distichon) Cultivars"

Mut Z., Sirat A. ve Sezer İ., 2014. Samsun koşullarında bazı iki sıralı arpa (Hordeum vulgare conv. distichon) genotiplerinde tane verimi ile başlıca tarımsal özelliklerin belirlenmesi ve stabilite analizi. Yüzüncü Yıl Üniversitesi, Tarım Bilimleri Dergisi, 24(1): 60-69

Sirat A., Sezer I. ve Mut Z., 2012. Bazı kışlık arpa (Hordeum vulgare L.) çeşitlerinin genotip $\mathrm{x}$ çevre interaksiyonları ve stabilitelerinin belirlenmesi. Gümüşhane Üniversitesi, Fen Bilimleri Enstitüsü Dergisi, 2(2): 68-75

Sirat A. ve Sezer İ., 2013. Samsun ekolojik koşullarında bazı iki ve altı sıralı arpa (Hordeum vulgare L.) genotiplerinin verim ve verim unsurları ile kalite özelliklerinin belirlenmesi. Yüzüncü Yıl Üniversitesi, Tarım Bilimleri Dergisi, 23(1): 10-17
Sirat A., 2014. Orta karadeniz bölgesi koşullarına uygun maltlık ve yemlik arpa (Hordeum vulgare L.) çeşitlerinin belirlenmesi. Namık kemal Üniv., Tekirdağ Zir. Fak. Derg., 11(1): 9-17

Şehirali S., Orta H. ve Başer İ., 2001. Trakya bölgesinde üretilen ekmeklik buğdayların çeşit-su- verim-kalite kriterlerinin belirlenmesi. Proje No: Tarp-2110

Townsend N., 2008. Barley Outlook for 2008. http://www.cwb.ca/public/en/newsroom/events/ grainworld/present/pdf/022508_ntownsend.pdf (Erişim tarihi: 17.08.2013) 